Artikel Penelitian

\title{
Analisis Frekuensi Pribadi Dan Modus Getar Struktur Pesawat Tanpa Awak Tipe Flying Wings
}

\author{
Lovely Son, Rachmad Afandi \\ Jurusan Teknik Mesin, Fakultas Teknik, Universitas Andalas, Kampus Limau Manis, Padang, 25163, Indonesia
}

INFORMASI ARTIKEL

Sejarah Artikel:

Diterima Redaksi: 06 Agustus 2018

Revisi Akhir: 24 September 2018

Diterbitkan Online: 29 Oktober 2018

KATA KUNCI

Frekuensi pribadi

Modus getar

UAV

Rib

Spar

KORESPONDENSI

E-mail: lovelyson@ft.unand.ac.id

\author{
A B S T R A C T
}

One of the important consideration in designing an unmanned aerial vehicle (UAV) is the dynamics characteristic of UAV structure. The dynamics characteristic of UAV structure can be evaluated from its dynamic parameters such as : natural frequencies and mode shape. These parameters play an important role in determining the system's dynamic response. In general, a low stiffness structure is more sensitive to the dynamic load in comparison with a high stiffness structure. In this research, modification UAV structural stiffness is conducted by varying rib and spar number and configuration on UAV wing. Evaluation of rib and spar number and configuration effect to the natural frequency and mode shape of UAV structure is conducted numerically and experimentally. The simulation results show that the natural frequencies increases with increasing of the number of spar and decreases with decreasing of the number of rib

\section{PENDAHULUAN}

Pesawat tanpa awak atau UAV (Unmanned Aerial Vehicle), merupakan salah satu piranti yang berkembang pesat untuk aplikasi penginderaan jauh. UAV adalah jenis pesawat terbang yang dikendalikan oleh sistem kendali jarak jauh lewat gelombang radio[1]. Pesawat ini tidak menggunakan pilot dan bisa bergerak secara otomatis dengan bantuan alat elektronik[2]. Sejauh ini UAV telah digunakan untuk mendapatkan citra pengideraan jauh untuk berbagai keperluan, seperti fotografi udara, survey daerah, pengintaian dari udara, dan penelitian kelautan serta pertanian. Selain itu dibandingkan dengan pesawat konvensional, UAV lebih mudah tersedia dan dapat menjangkau area yang cukup luas, dengan perlengkapan sensor yang relatif kecil.

Kinerja pesawat tanpa awak dapat dipengaruhi oleh getaran yang timbul pada saat terbang. Getaran ini biasanya muncul pada frekuensi tertentu yang disebut dengan frekuensi pribadi. Apabila suatu benda bergetar pada salah satu frekuensi pribadinya maka akan terbentuk suatu pola getaran yang disebut dengan modus getar [3].

Nilai frekuensi pribadi dan modus getar pada pesawat tanpa awak merupakan salah satu faktor yang perlu diperhatikan dalam perancangan UAV. Besar kecilnya nilai ini dipengaruhi oleh bentuk dan struktur dari pesawat tanpa awak tersebut[4]. 
Pesawat tanpa awak tipe flying wings merupakan salah satu bentuk UAV yang sering dipakai karena alasan bentuk dan strukturnya yang lebih aerodinamis. Pesawat jenis ini tidak memiliki badan sejati (definite fuselage) dan ekor horizontal (horizontal tail) sehingga menghasilkan drag surface yang lebih kecil. Pesawat tanpa awak tipe flying wings memiliki sepasang wings aerofoil dengan ketahanan (range and endurance) yang lebih baik dibandingkan dengan pesawat tanpa awak konvensional. Disamping itu, UAV jenis ini memiliki rib dan spar sebagai penguat dari struktur sayap pesawat sehingga dapat mempertahankan bentuk dari sayap ketika menerima beban pada bagian kulit sayap pesawat[5-7]. Jumlah dan konfigurasi rib dan spar memungkinkan modifikasi harga frekuensi pribadi dan modus getar pada pesawat UAV, sehingga didapatkan karakteristik dinamik sayap yang lebih baik.

Berdasarkan penjelasan di atas, analisis teoritik dan pengujian harga frekuensi pribadi dan modus getar pada pesawat tanpa awak tipe flying wings penting untuk dilakukan. Akan tetapi penelitian tentang analisis teoritik dan eksperimental tersebut belum banyak dilakukan di Indonesia. Oleh sebab itu penulis tertarik untuk meneliti bagaimana gambaran frekuensi pribadi dan modus getar pada UAV tipe flying wings dan menganalisisnya secara komprehensif.

Pada tulisan ini dilakukan kaji numerik dan eksperimental untuk mendapatkan harga frekuensi pribadi dan modus getar pada pesawat tanpa awak. Disamping itu juga ditinjau pengaruh jumlah dan konfigurasi rib dan spar terhadap nilai frekuensi pribadi dan modus getar pesawat. Hasil ini dapat digunakan sebagai referensi dalam memilih bentuk struktur pesawat yang tepat dalam perancangan pesawat tanpa awak ditinjau dari karaktersitik dinamiknya.

\section{TINJAUAN PUSTAKA}

\subsection{Frekuensi Pribadi}

Hubungan antara frekuensi getaran dengan sifatsifat benda yang bergetar dapat ditelusuri melalui simpangan benda $(y)$. Suatu benda yang bergetar pada prinsipnya dibangun oleh dua elemen utama yaitu elemen massa $(m)$ dan elemen $\operatorname{pegas}(k)$ seperti diperlihatkan pada Gambar 1.

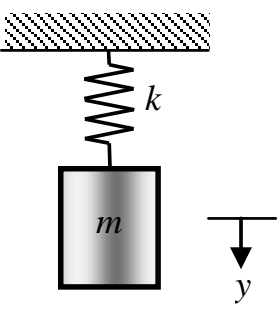

Gambar 1. Sistm getaran 1 DOF

Persamaan gerak sistem pada Gambar 1 dapat dituliskan sebagai berikut:

$m a=-k y$

Pada Pers.(1), $a$ adalah percepatan sistem. Dalam kondisi getaran bebas akibat pemberian simpangan atau kecepatan awal, respon perpindahan sistem merupakan fungsi harmonik sehingga dapat dituliskan sebagai berikut:

$y=A \cos \left(\omega t+\varphi_{0}\right)$

dengan $A$ dan $\varphi_{0}$ adalah konstanta. Konstanta $A$ dikenal dengan amplitudo, yaitu simpangan maksimum benda yang berosilasi, $\omega$ dikenal dengan frekuensi sudut getar, dan $\varphi_{0}$ dikenal dengan fasa getaran. Dengan menggunakan asumsi simpangan pada persamaan (2) maka respons kecepatan dan percepatan dapat dituliskan sebagai berikut:

$v=\frac{d y}{d t}=-\omega A \sin \left(\omega t+\varphi_{0}\right)$

$a=\frac{d v}{d t}=-\omega A \cos \left(\omega t+\varphi_{0}\right)$

Jika persamaan (2) dan (4) disubstisusikan dalam persamaan (1), maka diperoleh frekuensi pribadi system sebagai berikut:

$\omega=\sqrt{\frac{k}{m}}$

Mengingat $\omega=\frac{2 \pi}{T}=2 \pi f$ maka frekuensi pribadi system getaran 1 DOF memenuhi persamaan: 
$f=\frac{1}{2 \pi} \sqrt{\frac{k}{m}}$

\subsection{Pesawat tanpa awak tipe flying wings}

Pesawat tanpa awak tipe flying wings merupakan salah satu jenis UAV yang sering digunakan dalam aplikasi di lapangan karena bentuk dan strukturnya yang lebih aerodinamis. Pesawat jenis ini tidak memiliki badan sejati (definite fuselage) dan ekor horizontal (horizontal tail) sehingga menghasilkan drag surface yang lebih kecil. Pesawat jenis ini memiliki sepasang wings aerofoil dengan ketahanan (range and endurance) yang lebih baik dibandingkan dengan pesawat tanpa awak konvensional. Disamping itu, UAV jenis ini memiliki rib dan spar sebagai penguat dari struktur sayap pesawat sehingga dapat mempertahankan bentuk dari sayap ketika menerima beban pada bagian kulit sayap pesawat. Contoh UAV tipe flying wings dapat dilihat pada Gambar 2.

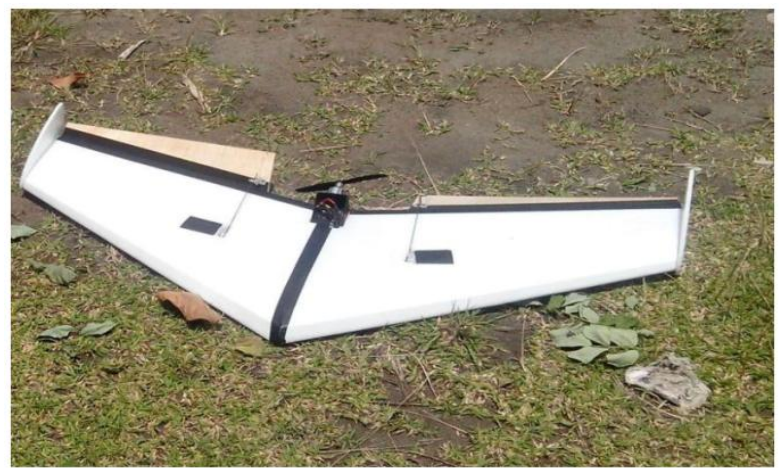

Gambar 2. Contoh UAV tipe flying wings[6]

\subsection{Analisis elemen hingga struktur UAV}

Beberapa penelitian telah dilakukan terkait pengimplementasian metode elemen hingga pada struktur pesawat menggunakan bantuan perangkat lunak komputer seperti ANSYS[8]. Katon Matzaini, et al.[9] menggunakan prinsip metode elemen hingga untuk analisis statis struktur pesawat tanpa awak seperti terlihat pada Gambar 3. Pada penelitian ini metode elemen hingga digunakan untuk menganalisis frekuensi pribadi dan modus getar struktur pesawat tanpa awak.

Gupta A, et al.[4] melaporkan teknik model updating pada metode elemen hingga menggunakan data hasil eksperimen yang dilakukan oleh Moreno et al. pada pesawat BFF (Body Freedom Flutter). BFF merupakan pesawat tanpa awak tipe flying wings dengan airfoil ringan yang tersusun dari badan tengah yang kaku dan dua sayap yang fleksibel seperti diperlihatkan pada Gambar 3. Modus getar serta frekuensi pribadi yang diperoleh ditampilkan pada Tabel 1.

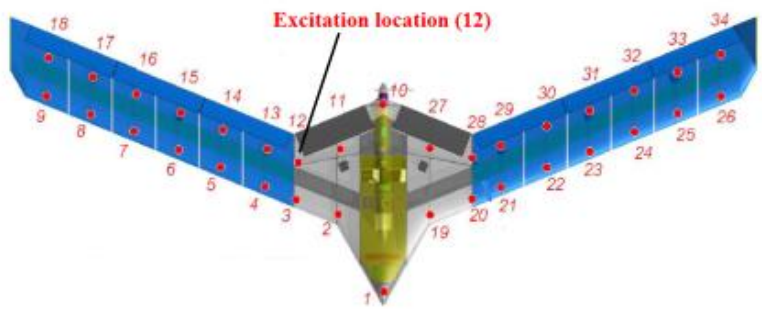

Gambar 3. Pesawat BFF [4]

Tabel 1. Modus getar, frekuensi pribadi dan rasio redaman pesawat tanpa awak [4]

\begin{tabular}{|c|c|c|}
\hline \multirow{2}{*}{ Mode Shape } & \multicolumn{2}{|c|}{ Identified Data } \\
\cline { 2 - 3 } & Freq [Hz] & Damp [\%] \\
\hline Sym 1st Bending & 5.67 & 1.55 \\
A/S 1st Bending & 8.37 & 1.06 \\
Sym 1st Torsion & 18.34 & 2.06 \\
A/S 1st Torsion & 19.82 & 2.33 \\
Sym 2nd Bending & 23.17 & 2.85 \\
A/S 2nd Bending & 28.60 & 2.55 \\
\hline
\end{tabular}

\section{METODOLOGI}

Pada Gambar 4 diperlihatkan tahapan-tahapan yang dilakukan dalam penelitian. Penelitian dimulai dengan studi literatur. Selanjunya dilakukan persiapan dan pembuatan pesawat. Pada tahap persiapan dilakukan perancangan pesawat berdasarkan perangkat lunak CAD/CAM. Tahap berikutnya adalah analisis dinamik struktur pesawat menggunakan simulasi numerik dan eksperimen. Analisis numerik menggunakan program elemen hingga[10]. Validasi dilakukan untuk melihat tingkat kesesuaian hasil simulasi dengan data pengujian. Pada tahap akhir dilakukan pengujian pengaruh variasi rib dan spar terhadap frekuensi pribadi struktur pesawat. 


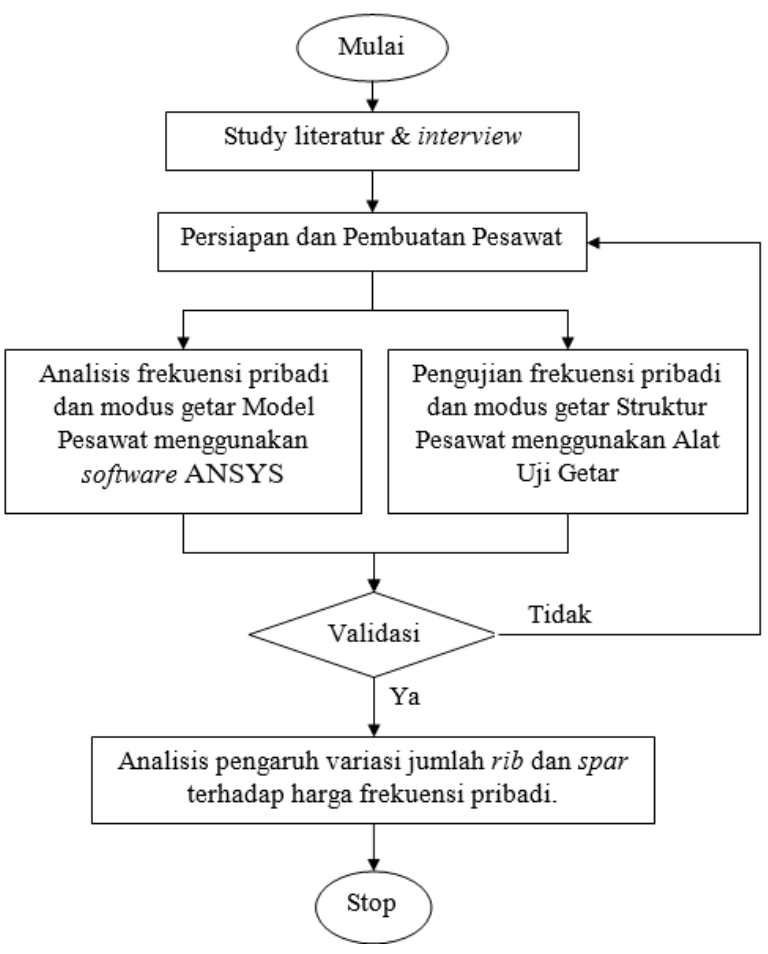

Gambar 4. Diagram alir penelitian

Berikut dijelaskan tentang tahapan-tahapan penelitian berdasarkan Gambar 4.

\subsection{Persiapan dan pembuatan pesawat}

Model pesawat yang diteliti mula-mula dirancang menggunakan perangkat lunak CAD/CAM komersil seperti diperlihatkan pada Gambar 5. Bahan yang digunakan untuk pembuatan rib dan spar pada sayap pesawat adalah kayu balsa dan alumunium, sedangkan kulit luar sayap pesawat menggunakan bahan yang terbuat material komposit.

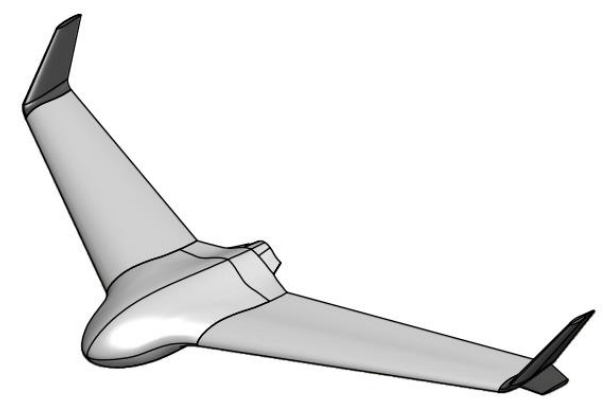

Gambar 5. Model pesawat yang digunakan dalam Penelitian

\subsection{Tahap simulasi}

Pada tahap ini dilakukan simulasi menggunakan perangkat lunak ANSYS untuk mendapatkan harga frekuensi pribadi dan bentuk modus getar struktur pesawat.

\subsection{Tahap pengujian}

Pada tahap ini dilakukan pengujian untuk mendapatkan harga frekuensi pribadi dan modus getar dari struktur pesawat. Data yang diperoleh dari pengujian digunakan untuk validasi hasil yang diperoleh dari simulasi.

Apabila hasil pengujian menunjukkan kemiripan harga frekuensi pribadi dan modus getar dengan hasil simulasi maka pemodelan dapat digunakan sebagai bahan masukan bagi proses perancangan pesawat. Selanjutnya dilakukan analisis pengaruh jumlah rib dan spar pada sayap terhadap harga frekuensi pribadi pesawat.

Apabila tidak terdapat kesamaan antara hasil simulasi dan eksperimen maka dilakukan evaluasi pada perancangan model pesawat untuk penelitian berikutnya.

Harga frekuensi pribadi dan modus getar pada struktur pesawat diuji dengan menggunakan alat pencuplik data buatan National Instrument. Sensor accelerometer ditempelkan pada struktur pesawat yang digantung pada batang penyangga. Selanjutnya pesawat diberikan gaya eksitasi berupa pukulan dengan impact hammer pada sisi vertikal yang berseberangan dengan posisi accelerometer. Data gaya eksitasi dan percepatan selanjunya dicuplik dengan NI Digital Signal Analyzer yang terhubung ke komputer pengujian. Selanjutnya data diolah menggunakan software MATLAB. Susunan perangkat uji getar pada pesawat dapat dilihat pada Gambar 6. 


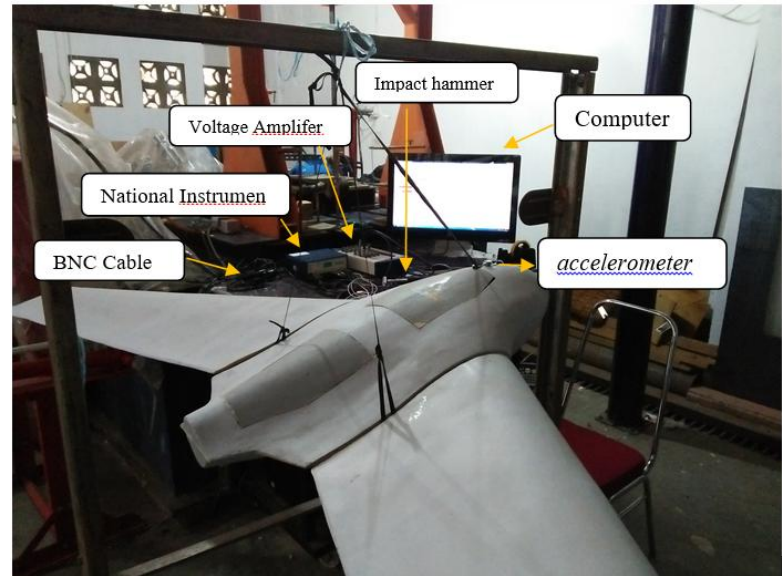

Gambar 6. Perangkat Uji

\section{HASIL DAN PEMBAHASAN}

\subsection{Perbandingan hasil simulasi dan eksperimen}

Pada Gambar 7 s/d 9 ditampilkan tiga buah modus getar elastis terendah pesawat yang diperoleh dari hasil simulasi menggunkan program ANSYS.

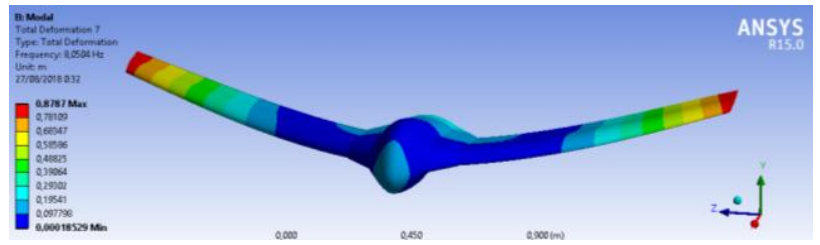

Gambar 7. Hasil simulasi modus elastis 1,

$$
f_{1}=8,1 \mathrm{~Hz}
$$

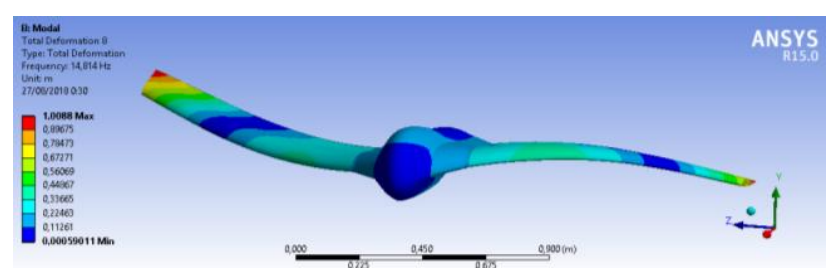

Gambar 8. Hasil simulasi modus elastis 2,

$$
f_{2}=14.8 \mathrm{~Hz}
$$

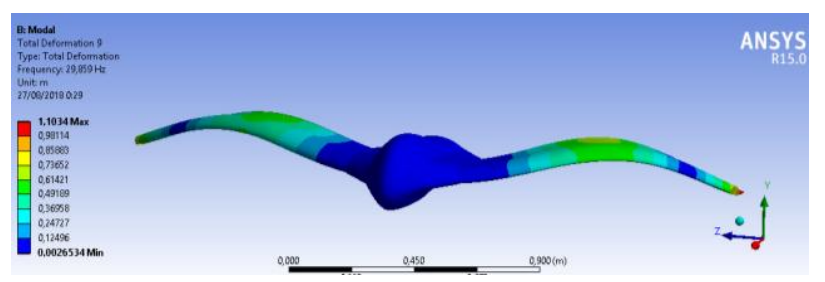

Gambar 9. Hasil simulasi modus elastis 3,

$$
f_{3}=29.9 \mathrm{~Hz}
$$

Selanjunya pada Gambar 10 s/d 12 ditunjukkan tiga buah modus getar elastis terendah yang diperoleh dari hasil pengujian.

Harga frekuensi pribadi struktur pesawat yang diperoleh dari kaji numerik mendekati hasil yang diperoleh dari eksperimen. Perbedaan cukup besar terjadi pada frekuensi pribadi pertama. Pada modus ini, frekuensi pribadi yang diperoleh secara numerik sebesar $8,1 \mathrm{~Hz}$ sedangkan pada eksperimen diperoleh sebesar 2,3 Hz.

Perbedaan pada harga frekuensi pribadi pertama kemungkinan disebabkan oleh kondisi sambungan struktur yang tidak sempurna. Pada frekuensi dua dan tiga diperoleh hasil yang hampir sama antara simulasi dan eksperimen. Perbandingan nilai frekuensi pribadi hasil eksperimen dan simulasi dapat dilihat pada Table 2

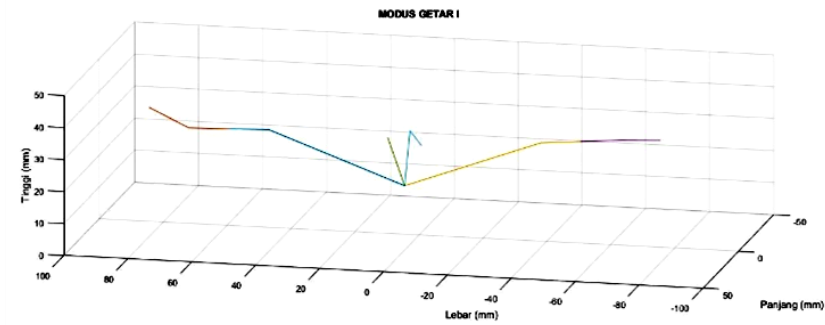

Gambar 10. Hasil pengujian modus elastis 1,

$$
f_{1}=2,3 \mathrm{~Hz}
$$

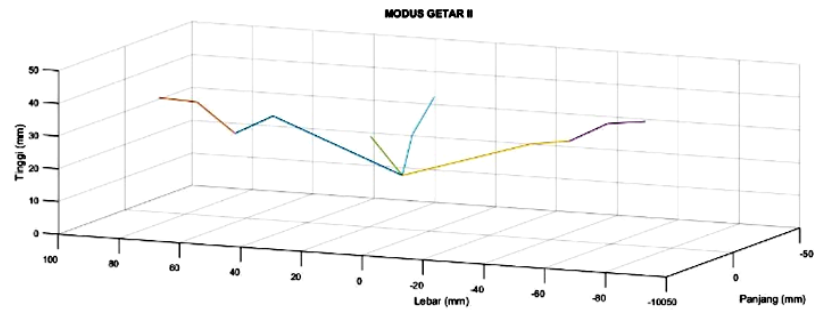

Gambar 11. Hasil pengujian modus elastis 2,

$$
f_{2}=13,8 \mathrm{~Hz}
$$

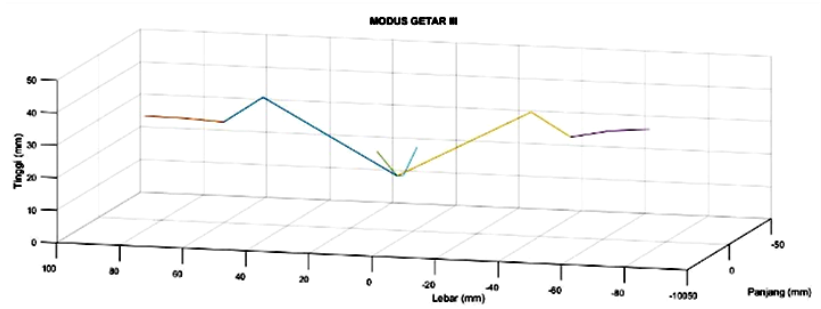

Gambar 12. Hasil pengujian modus elastis 3, $f_{3}=28,4 \mathrm{~Hz}$ 
Tabel 2. Perbandingan modus getar dan frekuensi pribadi

\begin{tabular}{ccc}
\hline Modus & $\begin{array}{c}\text { Frekuensi } \\
\text { Eksperimen } \\
{[\mathrm{Hz}]}\end{array}$ & $\begin{array}{c}\text { Frekuensi } \\
\text { Numerik } \\
{[\mathrm{Hz}]}\end{array}$ \\
\hline 1 & 2,3 & 8,1 \\
2 & 13,8 & 14,8 \\
3 & 28,4 & 29,9 \\
\hline
\end{tabular}

\subsection{Analisis pengaruh rib dan spar}

Variasi jumlah dan konfigurasi rib serta spar digunakan untuk melihat pengaruh kedua variable tersebut terhadap harga frekuensi pribadi pada pesawat. Dalam hal ini, variasi dilakukan sebagai berikut:

1. 6 rib tanpa menggunakan spar miring

2. 6 rib menggunakan spar miring

3. 8 rib tanpa menggunakan spar miring

4. 8 rib menggunakan spar miring

Dari analisis yang dilakukan pada variasi rib dan spar menggunakan software ANSYS diperoleh data seperti diperlihatkan pada Tabel 3:

Tabel 3. Perbandingan Harga Frekuensi Pribadi dari Masing-Masing Variasi

\begin{tabular}{c|rrrr}
\hline \multirow{2}{*}{ Modus } & \multicolumn{2}{|c}{$\begin{array}{c}\text { Frekuensi } \\
\text { PribadiTanpa } \\
\text { Spar [Hz] }\end{array}$} & \multicolumn{2}{c}{$\begin{array}{c}\text { Frekuensi } \\
\text { Pribadi dengan } \\
\text { Spar [Hz] }\end{array}$} \\
\cline { 2 - 5 } & 6 RIB & 8 RIB & 6 RIB & 8 RIB \\
\hline 1 & 8.41 & 8.15 & 8.55 & 8.36 \\
2 & 15.36 & 14.69 & 15.46 & 15.11 \\
3 & 30.31 & 29.60 & 31.09 & 31.29 \\
4 & 36.31 & 36.14 & 37.81 & 37.82 \\
\hline
\end{tabular}

Pada Tabel 3 terlihat bahwa nilai frekuensi pribadi menggunakan spar miring lebih tinggi dibandingkan tanpa menggunakan spar miring. Hal ini dapat disebabkan karena pengaruh spar cukup besar terhadap harga frekuensi pribadi pesawat.
VARIASI 6 RIB

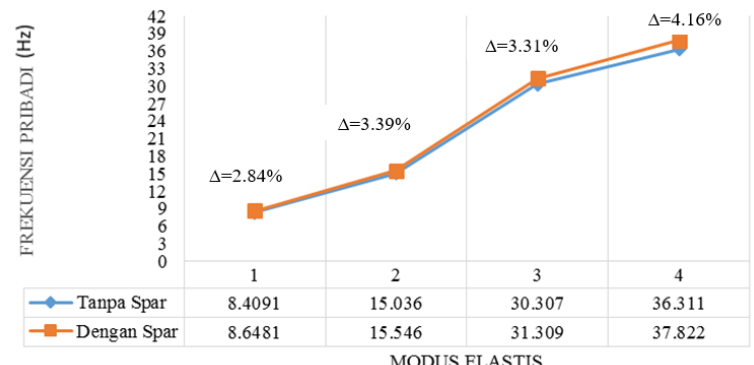

Gambar 13. Perbandingan Harga Frekuensi Pribadi Variasi 6 Rib

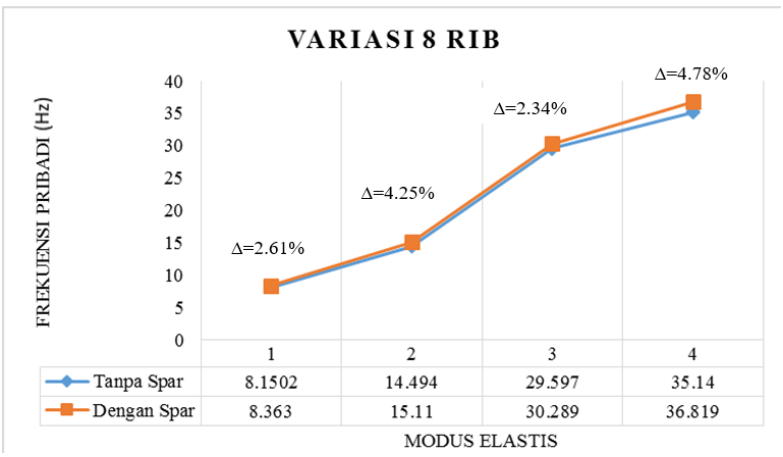

Gambar 14. Perbandingan Harga Frekuensi Pribadi Variasi 8 Rib

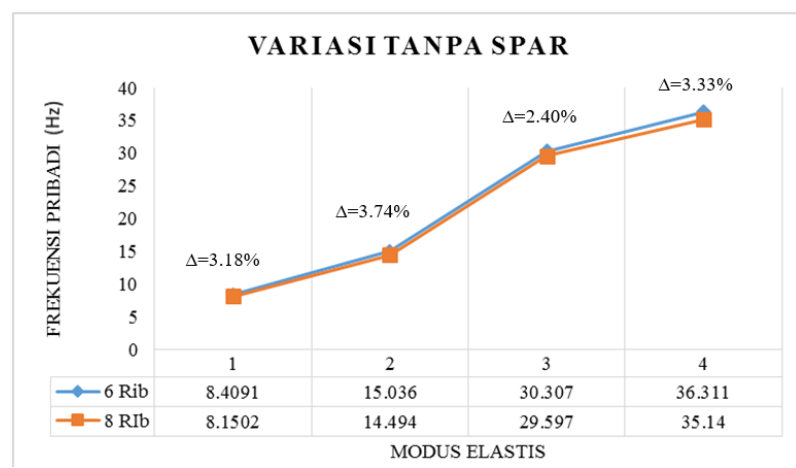

Gambar 15. Perbandingan Harga Frekuensi Pribadi Tanpa Menggunakan Spar Miring

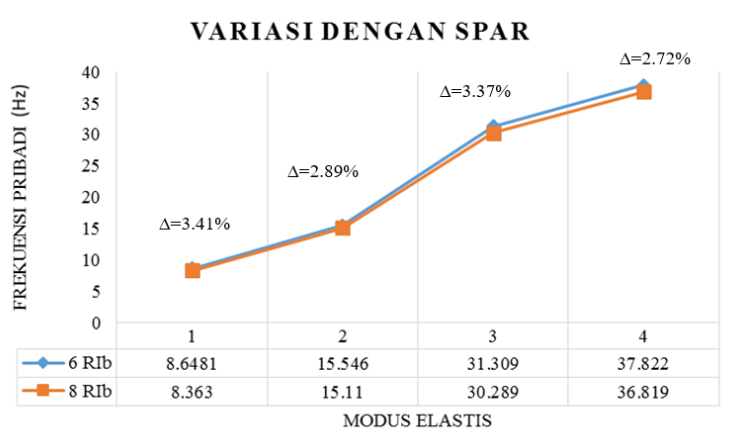

Gambar 16. Perbandingan Harga Frekuensi Pribadi Menggunakan Spar Miring 
Dari perbandingan yang telah dilakukan dapat di rangkum bahwa, pada variasi 6 rib, harga frekuensi pribadi pada pesawat yang menggunakan spar lebih tinggi dari pada tanpa menggunakan spar, begitu juga pada Gambar variasi 8 rib. Hal ini dapat disebabkan karena pesawat yang menggunakan spar memiliki tingkat kekakuan yang lebih tinggi.

Sementara itu, pada perbandingan variasi jumlah rib tanpa menggunakan spar harga frekuensi pribadi pada pesawat dengan jumlah rib enam (6) lebih tinggi dibandingkan pesawat dengan jumlah rib delapan (8), begitu juga pada perbandingan variasi jumlah rib dengan menggunakan spar. Hal ini disebabkan karena semakin sedikit jumlah rib, maka massa pesawat akan semakin rendah. Besarnya massa berbanding terbalik dengan nilai frekuensi pribadi sehingga pesawat dengan jumlah rib yang lebih sedikit (6) akan memiliki harga frekuensi pribadi yang lebih besar dibandingkan pesawat dengan jumlah rib yang lebih banyak (8) pada tingkat kekakuan yang sama.

\section{KESIMPULAN DAN SARAN}

1. Harga frekuensi pribadi dan modus getar pesawat tanpa awak tipe flying wings yang diperoleh dari simulasi menggunakan software ANSYS dan pengujian tidak jauh berbeda.

2. Harga frekuensi pribadi pesawat tanpa awak tipe flying wings dipengaruhi oleh jumlah variasi rib dan spar yang digunakan. Harga frekuensi pribadi berbanding terbalik dengan banyaknya jumlah variasi rib, dan berbanding lurus dengan adanya spar.

\section{UCAPAN TERIMA KASIH}

Penulis mengucapkan terima kasih kepada jurusan Teknik Mesin Universitas Andalas atas bantuan dana dari hibah penelitian jurusan tahun 2017.

\section{DAFTAR PUSTAKA}

[1] R. Shofiyanti, "Teknologi Pesawat Tanpa Awak Untuk Pemetaan dan Pemantauan Tanaman dan Lahan Pertanian,'Informatika Pertanian, Vol.20, No.2, hal: 58-64.

[2] A.K.B. Ajie, Penerapan Mikrokontroler AVR Dalam Pembuatan UAV Sebagai Sarana Fotografik Udara. Skripsi. Semarang: Universitas Diponegoro, 2007.

[3] Islahuddin, dkk., "Kajian Eksperimental Parameter Modal Bangunan Dua Lantai dengan Metode Modal Analisis," Jurnal Energi dan Manufaktur, Vol.9, No.1, hal: 91-97, 2016.

[4] A. Gupta et al., "Updating a Finite Element Based Structural Model of a Small Flexible Aircraft," USA: American Institute of Aeronautics and Astronautics, 2015.

[5] S.M. Abdullah et al., "Aerodynamics of a Flying Wing UAV with Backward Facing Stepped Wing Profile," Applied Sciences and Technology (IBCAST), Islamabad: IEEE, 2017.

[6] A. Basukesti, "Perancangan Sistem TeleNavigation Pada Pesawat Tanpa Awak (Micro UAV)," Jurnal SIMETRIS, Vol.7, No.1, hal: 105-110, 2016.

[7] T.H.G. Megson, Aircraft Structures for Engineering Students. Fourth Edition. Oxford: Elsevier, 2007.

[8] H.R. Chauhan et al. "Structural Design \& Optimization of An Unmanned Aerial Vehicle Wing For SAE Aero Design Challenge," International Journal of Advance Research and Innovation, Vol.1, Issue.1, pp: 24-29, 2017.

[9] M. Katon et al., "Static Structural Analysis of Blended Wing Body II-E2 Unmanned Aerial Vehicle,'Journal of Applied Environmental and Biological Sciences, Vol.7, No.6, pp: 91-98, 2017.

[10] H. Suryanto, Aplikasi Metode Elemen Hingga Untuk Analisa Struktur Statik Linier Dengan Program MSC/Nastran, Makalah. Malang: Universitas Negeri Malang. 